Vol 10, Issue 9, 2017

Online - 2455-3891

Print - 0974-2441

$\underline{\text { Research Article }}$

\title{
ANTIMICROBIAL ACTIVITY OF A PROTEASE INHIBITOR ISOLATED FROM THE RHIZOME OF CURCUMA AMADA
}

\author{
SANGEETHA R*, PADMINI R \\ Department of Biochemistry, School of Life Sciences, Vels University, Chennai - 600 117, Tamil Nadu, India. Email: sara_dna@yahoo.co.in \\ Received: 03 March 2017, Revised and Accepted: 23 May 2017
}

\begin{abstract}
Objective: Protease inhibitors (PIs) are effective antimicrobial agents, and this study was aimed to study the antibacterial efficacy of a PI isolated from the rhizome of Curcuma amada.

Methods: A proteinaceous protease inhibitor was isolated from the rhizome of $C$. amada and purified by Sephadex G-50 gel permeation chromatography. The purified inhibitor was denoted as Curcuma amada protease inhibitor (CAPI). The antibacterial effect of CAPI against Gram-positive and Gramnegative bacteria, the minimal inhibitory concentration (MIC), and minimal bactericidal concentration (MBC) of CAPI was studied in vitro, and the membrane disruption activity of CAPI was also analyzed.
\end{abstract}

Results: CAPI was effective against both Gram-positive and Gram-negative bacteria, with slightly higher concentrations required for Gram-negative bacteria. The MIC ranged from 75 to $100 \mu \mathrm{g} / \mathrm{ml}$ and the MBC ranged from 100 to $125 \mu \mathrm{g} / \mathrm{ml}$ of CAPI. The study of membrane disruption by CAPI revealed the release of cell contents, namely, reducing sugars and proteins from the bacterial cell.

Conclusion: A PI was effectively isolated from the rhizome of $C$. amada, and the isolated inhibitor proved to be a promising antibacterial agent.

Keywords: Curcuma amada rhizome, Protease inhibitor, Antibacterial activity, Minimal inhibitory concentration, Minimal bactericidal concentration.

(C) 2017 The Authors. Published by Innovare Academic Sciences Pvt Ltd. This is an open access article under the CC BY license (http://creativecommons. org/licenses/by/4. 0/) DOI: http://dx.doi.org/10.22159/ajpcr.2017.v10i9.18257

\section{INTRODUCTION}

Antimicrobial peptides are present in a wide variety of organisms, including animals, plants, microbes, and insects. These peptides are crucial components of defense strategy adopted by organisms to combat pathogens. These peptides belong to several subfamilies, the most prominent being protease inhibitors (PIs) [1].

PIs are ubiquitous in nature and play multiple roles in plants and animals. These compounds help to regulate metabolic pathways and maintain homeostasis. Plants produce these compounds that act as natural defenses against pests and pathogens. Plant PIs (PPIs) are generally small proteins or peptides present in tubers, seeds, and also in the aerial parts of plants [2]. The defensive capabilities of PIs rely on inhibition of proteases present in insect guts or secreted by microorganisms, causing a reduction in the availability of amino acids necessary for their growth and development [3]. PPIs are being researched for their medicinal values such as antimicrobial potential, anticarcinogenic activity, inhibition of blood coagulation, and antiinflammatory potential [4].

Mango ginger (Curcuma amada) is a perennial herb with modified stem called rhizome below the ground. It has morphological and phylogenic resemblance with ginger (Zingiber officinale) but imparts mango (Mangifera indica) flavor [5]. The mango ginger rhizome has been extensively used as appetizer, antipyretic, aphrodisiac, and laxative and to cure itching, skin diseases, bronchitis, asthma, and inflammation [6].

The objective of this study was to isolate and partially purify a PI from the rhizome of $C$. amada and to investigate the antibacterial potential of the purified inhibitor.

\section{METHODS}

All chemicals used in this study were of analytical grade.
Plant material

Fresh and healthy mango ginger (C. amada Roxb.) rhizomes were procured from the local market in Chennai, India. Rhizomes were washed and weighed. The rhizome was authenticated by Dr. J. Jayaraman, Plant Anatomy Research Center, Tambaram, Chennai, India (Voucher No. PARC/2016/1005).

\section{Preparation of crude extract}

$10 \mathrm{~g}$ of mango ginger was weighed and cut into small pieces using a sterile knife. The crude extract was obtained by grinding the small pieces using $30 \mathrm{ml}$ of $0.2 \mathrm{M}$ sodium phosphate buffer, $\mathrm{pH} 7.0$ in a mortar and pestle. It was mixed well using magnetic stirrer and then centrifuged at $2500 \mathrm{rpm}$ for 15 minutes. The supernatant was harvested and stored at $4^{\circ} \mathrm{C}$.

\section{Purification of PI}

\section{Ammonium sulfate precipitation}

Solid ammonium sulfate was added at various concentrations to the crude extract, and the precipitates were recovered by centrifuging at $20000 \mathrm{~g}$ at $4^{\circ} \mathrm{C}$ for 10 minutes. The precipitates were resuspended in $0.2 \mathrm{M}$ sodium phosphate buffer ( $\mathrm{pH} 7.0)$. The proteolytic activities in the precipitates were determined. The precipitates exhibiting low protease activities were resuspended in $0.2 \mathrm{M}$ sodium phosphate buffer (pH 7.0) and pooled for further use.

\section{Dialysis}

The resuspended precipitate was dialyzed extensively using $0.2 \mathrm{M}$ sodium phosphate buffer ( $\mathrm{pH} 7.0$ ). The protein content and proteolytic activities in the dialysate were determined.

\section{Gel filtration chromatography}

Ten milliliters of the dialysate was loaded onto a Sephadex G-50 column which had been pre-equilibrated with $0.5 \mathrm{M}$ Tris- $\mathrm{HCl}$ buffer of $\mathrm{pH} 7.0$ containing $0.5 \mathrm{M} \mathrm{NaCl}$ and eluted with the same buffer at a flow rate 
of $30 \mathrm{ml} / \mathrm{hr}$. All eluted fractions $(2 \mathrm{ml})$ were assayed for enzyme activities, and the fractions with high activities were pooled. The pooled fractions were subjected to dialysis against Tris- $\mathrm{HCl}$ buffer, and the enzyme activities in the dialysates were determined. The dialysate was lyophilized, denoted as curcuma amada protease inhibitor(CAPI), and stored at $4^{\circ} \mathrm{C}$ for further use.

\section{Trypsin and chymotrypsin assay}

Trypsin and chymotrypsin activity was assayed by the method of Rahman et al. [7]. A portion of the purified incubator was incubated for 10 minutes at $30^{\circ} \mathrm{C}$ with trypsin and chymotrypsin $(250 \mu \mathrm{g} / \mathrm{ml}$ in phosphate buffer, $\mathrm{pH}$ 7). $2 \mathrm{ml}$ of $1 \%$ casein (w/v) was then added and incubated for 10 minutes at $30^{\circ} \mathrm{C}$. The reaction was terminated by adding $2 \mathrm{ml}$ of $10 \%$ trichloroacetic acid. The reaction mixtures were centrifuged for 10 minutes at $10,000 \mathrm{~g}$. The supernatants were harvested. To $1.0 \mathrm{ml}$ of supernatant, $5.0 \mathrm{ml}$ of $0.4 \mathrm{M}$ sodium carbonate and Folin-Ciocalteu reagent (1:3 dilution) was added, and the resulting solution was read at $660 \mathrm{~nm}$

\section{Determination of antibacterial activity}

Antibacterial activity of sample was determined by disc diffusion method on Muller-Hinton Agar (MHA) medium. The inoculums were spread on the solid plates with a sterile swab moistened with the bacterial suspension.

The discs were placed in MHA plates, and $20 \mu \mathrm{l}$ of crude extract, $20 \mu \mathrm{l}$ of partially purified inhibitor $(100 \mu \mathrm{g})$, and different concentrations of the purified inhibitor (20-100 $\mu \mathrm{g})$, dimethyl sulfoxide (negative control), and ampicillin (positive control) were placed on the discs. The plates were incubated for $24 \mathrm{hrs}$ at $37^{\circ} \mathrm{C}$. Then, the microbial growth was determined by measuring of the zone of inhibition.

Determination of minimal inhibitory concentration (MIC) and minimal bactericidal concentration (MBC)

Different concentrations of the purified inhibitor $(25,50,75,100$, and $125 \mu \mathrm{g} / \mathrm{ml}$ ) were added to $20 \mu \mathrm{l}$ of bacterial inoculum in the wells of microtitre plate and incubated at $37^{\circ} \mathrm{C}$. The control well was devoid of inhibitor. The absorbance at $490 \mathrm{~nm}$ was measured at the end of the incubation period. MIC is the concentration of the inhibitor in the well which exhibits $\geq 50 \%$ reduction in absorbance of the control. For the determination of MBC, wells with concentrations of inhibitor which exhibited $\geq 50 \%$ reduction were chosen. Aliquots from those wells were transferred to Petri dishes containing nutrient agar and incubated at $37^{\circ} \mathrm{C}$. MBC corresponds to the concentration of the inhibitor which shows no bacterial growth.

\section{Study of bacterial membrane disruption}

Varying concentrations of the purified inhibitor $(25,50,75,100$, and $125 \mu \mathrm{g} / \mathrm{ml})$ were added to bacterial cultures $\left(10^{9} \mathrm{CFU} / \mathrm{ml}\right)$ and incubated at $37^{\circ} \mathrm{C}$. After $24 \mathrm{hrs}, 1 \mathrm{ml}$ of the culture was harvested and centrifuged, and the supernatant was analyzed for the presence of reducing sugars and proteins.

\section{RESULTS}

The crude extract was obtained from the rhizome, and the presence of PI was studied by analyzing the inhibition of the activity of trypsin and chymotrypsin. About $500 \mathrm{mg}$ of protein was present in the crude extract, and the inhibition of proteolytic activity was determined to be $7 \%$. Purification using ammonium sulfate fractionation followed by dialysis was performed. The dialysate thus obtained exhibited maximum inhibitory activity of $24 \%$. The partially purified inhibitor may contain other proteinaceous contaminants, and hence the inhibitor was subjected to gel filtration chromatography. The dialysate was further purified on Sephadex G-50 column, and the purified inhibitor exhibited $80 \%$ activity (Table 1 ).

The antibacterial activity of CAPI was evaluated against few Grampositive and Gram-negative bacteria such as Salmonella typhi, Escherichia coli, Pseudomonas aeruginosa, Bacillus subtilis, and Staphylococcus aureus. The efficacy of the purified inhibitor was comparable to the reference standard, ampicillin.

The crude extract was minimally effective on S. aureus and B. subtilis and absolutely no effect on the other tested bacteria. When compared to purified CAPI, the partially purified exhibited $50-60 \%$ of inhibitory activity. The purified CAPI showed significant activity against $S$. aureus, E. coli, B. subtilis, S. typhi, and P. aeruginosa. The highest activity was shown against $S$. aureus and $B$. subtilis, and the least activity was against S. typhi by both the partially purified and purified CAPI (Table 2).

The MIC and MBC ofCAPI for different bacterial species were determined. The MIC and MBC were found to be 75 and $125 \mu \mathrm{g} / \mathrm{ml}$, respectively, for Gram-positive bacteria and 100 and $125 \mu \mathrm{g} / \mathrm{ml}$, respectively, for Gram-negative bacterial species studied. The difference in MIC and MBC of Gram-positive and Gram-negative bacteria can be attributed to the presence of lipopolysaccharide capsule in Gram-negative bacteria which offers resistance to the PI [8].

Disruption of membrane activity was studied by analyzing the release of cell components in the cultures treated with different concentrations of purified CAPI. The release of reducing sugars and proteins were

Table 1: Purification profile of PI

\begin{tabular}{lllc}
\hline Purification steps & $\begin{array}{l}\text { Extent of inhibition } \\
\text { of trypsin (\%) }\end{array}$ & Protein (mg) & Yield (\%) \\
\hline Crude extract & 7 & 325 & 100 \\
Ammonium sulfate fractionation & 24 & 180 & 55.38 \\
Sephadex G-50 gel permeation chromatography & 80 & 85 & 3.4 \\
\hline
\end{tabular}

Values expressed as the mean of three independent experiments. PI: Protease inhibitor

Table 2: Antibacterial activity of CAPI

\begin{tabular}{|c|c|c|c|c|c|c|}
\hline \multirow[t]{3}{*}{ Bacteria } & \multicolumn{6}{|c|}{ Zone of inhibition (mm)* } \\
\hline & \multirow[t]{2}{*}{ CE } & \multirow[t]{2}{*}{ PP CAPI } & \multicolumn{4}{|c|}{ CAPI $(\mu \mathrm{g} / \mathrm{ml})$} \\
\hline & & & 25 & 50 & 75 & 100 \\
\hline Salmonella typhi & - & $06 \pm 1$ & $08 \pm 0.3$ & $09 \pm 0.6$ & $10 \pm 0.8$ & $12 \pm 0.5$ \\
\hline Escherichia coli & - & $06 \pm 0.5$ & $08 \pm 0.5$ & $10 \pm 0.2$ & $11 \pm 0.5$ & $13 \pm 0.5$ \\
\hline Pseudomonas aeruginosa & - & $07 \pm 0.3$ & $08 \pm 0.3$ & $10 \pm 0.6$ & $11 \pm 0.7$ & $12 \pm 0.8$ \\
\hline Bacillus subtilis & $03 \pm 0.3$ & $10 \pm 0.2$ & $11 \pm 0.2$ & $12 \pm 0.5$ & $14 \pm 0.4$ & $16 \pm 0.5$ \\
\hline Staphylococcus aureus & $03 \pm 0.6$ & $11 \pm 0.4$ & $13 \pm 0.5$ & $15 \pm 0.3$ & $16 \pm 0.6$ & $18 \pm 0.8$ \\
\hline
\end{tabular}

* Data represent mean \pm SD. p $<0.05$, -: No zone of inhibition, CE: Crude extract, PP CAPI: Partially purified curcuma amada protease inhibitor 


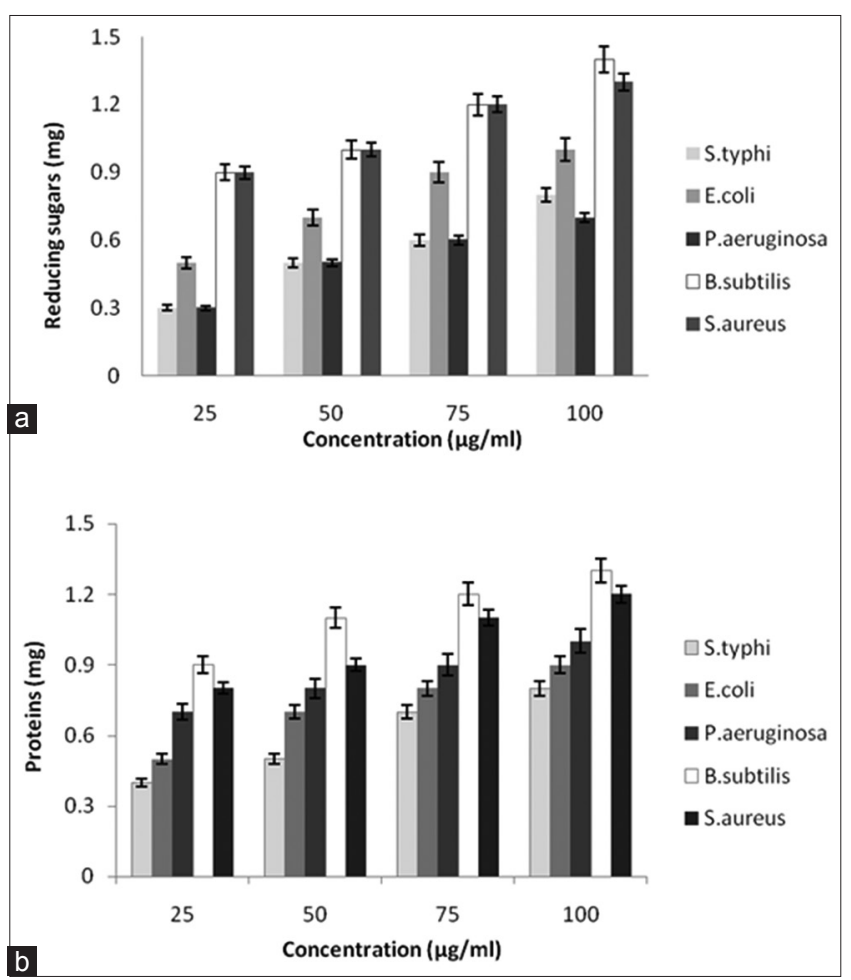

Fig. 1: Bacterial membrane disruption by curcuma amada protease inhibitor at the end of 24 hrs of incubation. (a) Release of reducing sugars, (b) release of proteins. Values represented are mean \pm standard deviation

studied at 0 and $24 \mathrm{hrs}$ of incubation. The results recorded at the end of 24 hrs of incubation are presented in Fig. 1.

\section{DISCUSSION}

PPIs are small peptides which are an integral part of the plant defense system. These inhibitors have several biomedical and clinical applications, and the biological activities of these inhibitors in animal models have been reported [9-11]. C. amada has several medicinal values as claimed traditionally, and most of these values have been confirmed scientifically [6]. The present study was intended to isolate a PI from C. amada and assesses its antibacterial activity. A novel PI, denoted as CAPI, was isolated and purified from the rhizome of C. amada. The inhibitor being proteinaceous in nature was satisfactorily purified using gel permeation chromatography. This was established by the yield and purification fold obtained at the end of the purification process.

PIs have been reported as antibacterial agents, the activity being attributed to the interaction of these inhibitors with the physiologically important proteases as well as with the proteins present in the cell wall or membrane. These interactions culminate in changes in membrane permeability and the death of the bacteria $[1,12]$.

CAPI exhibited antibacterial activity as effectively as the standard under the study, ampicillin. The antibacterial activity of the inhibitor improved with its purity. The elimination of coexisting proteins by gel filtration chromatography increased the antibacterial potential of the isolated inhibitor. The antibacterial activity of CAPI could be attributed to the effect of the inhibitor on the bacterial cell wall and membrane. Disruption of bacterial cell wall and membrane results in release of cellular contents such as reducing sugars and proteins. The gradual increase in the release of these components from the bacteria indicated that CAPI had disrupted the bacterial membrane during the incubation process, thereby releasing cell contents. The release of reducing sugars and proteins was directly proportional to the concentration of CAPI and the duration of incubation. Membrane disruption was prominent in B. subtilis, S. aureus, and P. aeruginosa when compared to S. typhi and E. coli. PPIs exhibit a dual role, wherein they suppress the activity of the pathogenic microorganisms' protease and also alter its membrane permeability, thus proving to be effective antimicrobial agents [13].

The results of the present investigation reveal that the PI CAPI isolated from the rhizome of $C$. amada has potential antibacterial activity. Further studies have been initiated to study the efficacy of CAPI in vivo. These studies will ascertain the application of CAPI as clinical agents. A similar study by Sukandar et al. has established the use of extracts of fingerroot rhizome as effective topical antibacterial agents [14].

\section{CONCLUSION}

A PI was isolated and partially purified from the rhizome of $C$. amada. The antibacterial activity of the inhibitor was studied, and the minimum inhibitor concentration required for its activity against Gram-positive and Gram-negative bacteria was identified. The effect of the inhibitor in altering the stability of the bacterial membrane was also studied and proposed that the inhibitor exerted its antibacterial effect through bacterial membrane disruption.

\section{REFERENCES}

1. Kim JY, Park SC, Hwang I, Cheong H, Nah JW, Hahm KS, et al. Protease inhibitors from plants with antimicrobial activity. Int $\mathrm{J}$ Mol Sci 2009;10(6):2860-72.

2. Park Y, Choi BH, Kwak JS, Kang CW, Lim HT, Cheong HS, et al. Kunitz-type serine protease inhibitor from potato (Solanum tuberosum L. cv. Jopung). J Agric Food Chem 2005;53(6):6491-6.

3. Arulpandi I, Sangeetha R. Antibacterial activity of fistulin: A protease inhibitor purified from the leaves of Cassia fistula. ISRN Pharm 2012;2012:584073.

4. Bijina B, Chellappan S, Krishna JG, Basheer SM, Elyas KK, Bahkali AH, et al. Protease inhibitor from Moringa oleifera with potential for use as therapeutic drug and as seafood preservative. Saudi J Biol Sci 2011;18(3):273-81.

5. Policegoudra RS, Chandrashekhar RH, Aradhya SM, Singh L. Cytotoxicity, platelet aggregation inhibitory and antioxidant activity of Curcuma amada Roxb. Extracts. Food Technol Biotechnol 2011;49 Suppl 2:162-8.

6. Policegoudra RS, Aradhya SM, Singh L. Mango ginger (Curcuma amada Roxb.) A promising spice for phytochemicals and biological activities. J Biosci 2011;36 Suppl 4:739-48.

7. Rahman RN, Geok LP, Basri M, Salleh AB. Physical factors affecting the production of organic solvent-tolerant protease by Pseudomonas aeruginosa strain K. Bioresour Technol 2005;96(4):429-36.

8. Mohammed NS, Srinivasulu A, Chittibabu B, Rao VU. Isolation and purification of antibacterial principle from Avicennia marina $\mathrm{L}$ in methanol. Int J Pharm Pharm Sci 2015;7(1):38-41.

9. Ribeiro JK, Cunha DD, Fook JM, Sales MP. New properties of the soybean trypsin inhibitor: Inhibition of human neutrophil elastase and its effect on acute pulmonary injury. Eur J Pharmacol 2010;644(13):238-44.

10. Mayasa V, Rasal VK, Unger BS. Evaluation of phenol content, antioxidant and proteinase inhibitory activity of plant derived protease inhibitors of eight anti-diabetic plants. Asian J Pharm Clin Res 2016;9(3):215-9.

11. Krishnan MV, Murugan K. Solanum protease inhibitors and their therapeutic potentialities. Int J Pharm Pharm Res 2016;8(12):14-21.

12. Paiva PM, Pontual EV, Coelho LC, Napoleao TH. Protease inhibitors from plants: Biotechnological insights with emphasis on their effects on microbial pathogens. In: Mendez-Vilas A, editor. Microbial Pathogens and Strategies for Combating Them: Science. Badajoz: Technology and Education, Formatex; 2013.

13. Kim JY, Park SC, Kim MH, Lim HT, Park Y, Hahm KS. Antimicrobial activity studies on a trypsin-chymotrypsin protease inhibitor obtained from potato. Biochem Biophys Res Commun 2005;330(3):921-7.

14. Sukandar EY, Fidrianny I, Kamil A. In situ antibacterial activity of Kaempferia pandurata (Roxb.) rhizomes against Staphylococcus aureus. Int J Pharm Pharm Sci 2015;7(2):239-44. 